\title{
Appreciation: Professor Samantha Hettiarachchi - an ambassador for science
}

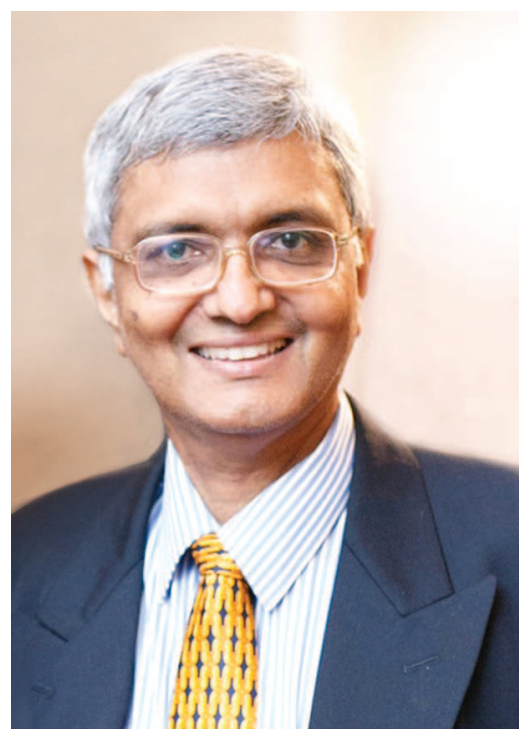

Samantha Hettiarachchi was educated at S. Thomas' College, Mt. Lavinia and graduated from the University of Moratuwa, specialising in civil engineering. He obtained his doctorate in 1987 at Imperial College, London, working on both physical and numerical modelling of coastal structures under wave loading. His investigations on single layer concrete armour units contributed to their later widespread use - for example in the Colombo South Port breakwater. From these early days of his research career, he displayed an interest and aptitude for taking science to practice. During his doctoral studies, he collaborated with the Hydraulics Research Station at Wallingford and later worked for a year at Ove Arup and Partners, probably the best known civil engineering consultancy firm in the world, while on special leave from Moratuwa University.

The National Science Foundation (NSF) (and its precursor NARESA) played a significant part in Professor Hettiarachchi's development and contributions as a scientist-engineer. He was able to secure grants from the NSF in his early career as a result of which he won two national merit awards. Later in his career he served on many NSF working committees (Engineering and Built Environment; Oceanography and Marine Resources; and International Liaison). He also served on the thematic committee on Disaster Management and Mitigation, and NSF's Research Advisory Board. From 2006 to 2011 he was a member of the editorial board of the Journal of the National Science Foundation, during which time the Journal succeeded in being included in the Science Citation Index Expanded. His international stature was such that the NSF invited him to moderate a science dialogue that the UNESCO Director General Irina Bokova had with the Sri Lankan scientific community in August 2016.

Professor Hettiarachchi's desire to take science to practice was manifested in the collaborations he cultivated with many state agencies - the Coast Conservation Department initially and the Disaster Management Centre later on. He designed many fishery harbours along our coast and was also involved in various studies on the Galle and Hambantota Ports and also Colombo's South Port. He had an intimate knowledge of the Sri Lankan coastline. As his interests grew wider he led or contributed to many environmental impact assessment studies, including ones on the Mattala Airport and the Port City. He always sought to balance the demands of development and conservation; his uncompromising integrity and intellectual independence helped him to handle controversy with equanimity. He also contributed to Sri Lanka's Coastal Zone Management Plan and its National Action Plan for Climate Change. He was consulted by the governments of Oman and Indonesia in addition to our own.

Perhaps his greatest role as a science ambassador for Sri Lanka was in the leadership he gave to the installation of the Indian Ocean Tsunami Warning and Mitigation System under the auspices of UNESCO, ending up as Vice-Chairman and Acting Chairman of its steering group. This involved reaching consensus among both bureaucrats and subject specialists from 26 Indian Ocean 
rim states. Under his leadership UNESCO has produced two definitive guidelines, on Tsunami Risk Assessment and Probabilistic Tsunami Hazard Analysis.

There are many other roles that Samantha played with distinction - thoroughbred academic, gifted teacher, methodical administrator, accessible mentor, brilliant orator, engaging raconteur, connoisseur collector of fountain pens, beloved son, amiable friend and devoted husband. But I will end by saying that in spite of his many achievements in a lifespan of just 62 years, he never took himself too seriously, never demanded obeisance from anyone, accorded dignity to all who crossed his path and lived very simply. Through his long and courageous battle with cancer he always adopted a positive outlook to life, made the most of what life gave him, and indeed was a source of counsel for others who suffered from the disease. He will be mourned and missed by us all, but especially by his wife and fellow engineering academic Premini, to whom we offer our condolences.

\section{Professor Priyan Dias Senior Professor in Civil Engineering University of Moratuwa} Former member of the Editorial Board/JNSF 